\title{
EFFECTS OF TEMPERATURE INCREMENTS ON JUVENILE STEELHEAD
}

\section{CPNT-710501- 42}

P. A. OTson*, E. G. Tangen and W. L. Templeton

Ecosystems Department

Pacific Northwest Laboratory

Battelle Memorial Institute

Richland, Washington 99352

Introduction

Studies to evaluate the effects of thermal increments on the development, mortality, hatching and growth of salmonid eggs and yound have been conducted at Hanford for several years to provide data on the potential effects of thermal increments from reactor effluents (01son and Foster, 1957; 01son, et a1., 1970). Past studies have emphasized the fall chinook salmon since the central Columbia River is heavily utilized as a spawning ground, and the Hanford reactors discharged large quantities of heated effluent into this region (Watson, 1970). The Columbia River also serves as a migratory route for upper river tributary stocks of steelhead, Salmo gairdneri Richardson and as spawning grounds for a stock in the Hanford area. In order to determine the effects of increased temperatures on the steelhead population, studies were initiated on the effects on the survival and growth of juvenile steelhead to provide some assurance that the normal increments from reactor effluents would not cause excessive mortality or growth depression, and to permit estimates of critical thermal levels.

\section{*Deceased}

\section{-NOTICE}

This report was prepared as an account of work This report was prepared as an Government. Neither sponsored by the Unite United States Atomic Energy the United States nor the Unire employees, nor any of Commission, nor any of their employee, nomployees, their contractors, subcontractors, or their employees, makes any warranty, express or implied, or assumes any legal liability or responsibility for the accuracy, comlegal liability or responsibing information, apparatus,
pleteness or usefulness of any

product or process disclosed, or represents
would not infringe privately owned rights. 


\section{DISCLAIMER}

This report was prepared as an account of work sponsored by an agency of the United States Government. Neither the United States Government nor any agency Thereof, nor any of their employees, makes any warranty, express or implied, or assumes any legal liability or responsibility for the accuracy, completeness, or usefulness of any information, apparatus, product, or process disclosed, or represents that its use would not infringe privately owned rights. Reference herein to any specific commercial product, process, or service by trade name, trademark, manufacturer, or otherwise does not necessarily constitute or imply its endorsement, recommendation, or favoring by the United States Government or any agency thereof. The views and opinions of authors expressed herein do not necessarily state or reflect those of the United States Government or any agency thereof. 


\section{DISCLAIMER}

Portions of this document may be illegible in electronic image products. Images are produced from the best available original document. 
Methods

Young fish, average weight $0.8 \mathrm{~g}$, were obtained from Washington State Department of Game as progeny of Columbia River steelhead spawned in the spring of 1969. Replicate sets of 75 fish each were maintained in standard troughs with flowing Columbia River water at ambient. temperature and with added increments of $\Delta T$ T.7C (3.OF), $\Delta T 2.2 C$ (4.OF) and $\Delta T 2.6 C(5.0 F)$. The temperature increments were checked daily and maintained relative to the seasonal temperature cycle of the Columbia River (Figure 1). The total-fish stock in each treatment were weighed frequently to provide data on average weights. In January 1970 replicates were combined and randomily reduced to 120 fish in each test temperature regime and maintained in $4^{\prime}$ diameter tanks with a volume of 4701 and with a flow rate of 16.01 per minute. The stocks were further reduced to 75 in each treatment in May 19:70:-. The study was terminated in January 1971 when fish were individuaity weighed and measured.

Mortalities in the first twelve months were within hatchery standards and did not appear to be correlated with relative temperature conditions. In the fall of 1969 some mortalities were associated with columnaris disease.

Maximum river water temperatures were experienced during the period mid-August to mid-September in each year. In 1969 the daily temperatures of the warmest test group averaged slightly over $21.1 \mathrm{C}$ during thịs period. In 1970 the warmest test group averaged over $21.9 \mathrm{C}$ in midAugust. 


\section{Results}

f In 1969 the high summer temperatures tended to slow the rate of growth (based on average weight) in the incremental groups, with the growth of the same groups favored during the winter months. In late 1970 the average weight of the fish in the warmest group was not maintained relative to the other two incremental groups. (Figure 2 and Figure 3). The overall increase in average weights for each group over the 18 months is shown in Figure 4.

When the fish stocks were reduced in the beginning of 1970 the fifty-nine excess fish were tested for incidence and infection for columnaris and furunculosis disease. All gill swabs were negative for columnaris and only two blood samples were positive for furunculosis. However, ten out of 18 fish sampled specifically for antibody production had significant titres indicating that a large proportion had been exposed to these disease organisms previously.

Analysis of the individual weight data taken in January 1971 is presented in Table I. The fish reared in the incremental temperature regimes were significantly heavier than those reared in ambient river water based on analysis of variance at 0.05 level of significance. However, there was no significant difference in the weights of the temperature incremental groups. 
Table I

\begin{tabular}{|c|c|c|c|c|c|}
\hline $\begin{array}{l}\text { Temperature } \\
\text { Regime }\end{array}$ & Mean Wt. & $\begin{array}{l}\text { No. of } \\
\text { Fish }\end{array}$ & Std. Dev. & Std. Error & $\begin{array}{l}95 \% \text { Confidence } \\
\quad \text { Interval } \\
\end{array}$ \\
\hline $\begin{array}{l}\text { Ambient } \\
\text { River }\end{array}$ & 264.7 & 74 & 160.3 & 18.6 & $227.5-301.8$ \\
\hline$+7.7 C$ & 302.4 & 71 & 155.0 & 18.4 & $265.7-339.7$ \\
\hline$+2.2 c$ & 375.5 & 68 & 132.8 & 16.1 & $283.3-347.7$ \\
\hline$+2.6 \mathrm{C}$ & 297.0 & 60 & 144.6 & 18.7 & $259.9-334.4$ \\
\hline $\begin{array}{l}\text { Incremental } \\
\text { Tests Alone }\end{array}$ & 305.3 & 199 & 144.3 & 17.7 & $269.9-340.7$ \\
\hline
\end{tabular}

Analysis of Individual Weights of Juvenile Chinook in January 1971. 
Discussion

Increased temperatures of a few degrees, such as might be experienced by steelhead below the Hanford reactors, appear to enhance the growth rate, especially when the ambient river temperatures are at their seasonal low. However, due to the inherent differences in growth rates of our fish we were unable to demonstrate any significant difference between the treatment temperatures employed.

The temperature regimes used did not appear to increase mortality in the first twelve months though there is a suggestion of increased mortalities in the two warmest treatments in the final six months of the experiment. 


\section{References}

01son, P. A., and R. F. Foster. 1957. Temperature tolerance of eggs and young of Columbia River chinook saimon. Trans. Amer. Fish. Soc. $85: 203-207$.

01son, P. A., R. E. Nakatani and T. Meekin. 1970. Effects of thermal increments on eggs and young of Columbia River fall chinook. USAEC R \& D Report;-BNWL-1538, Battel le-Northwest, Richland, Washington. 


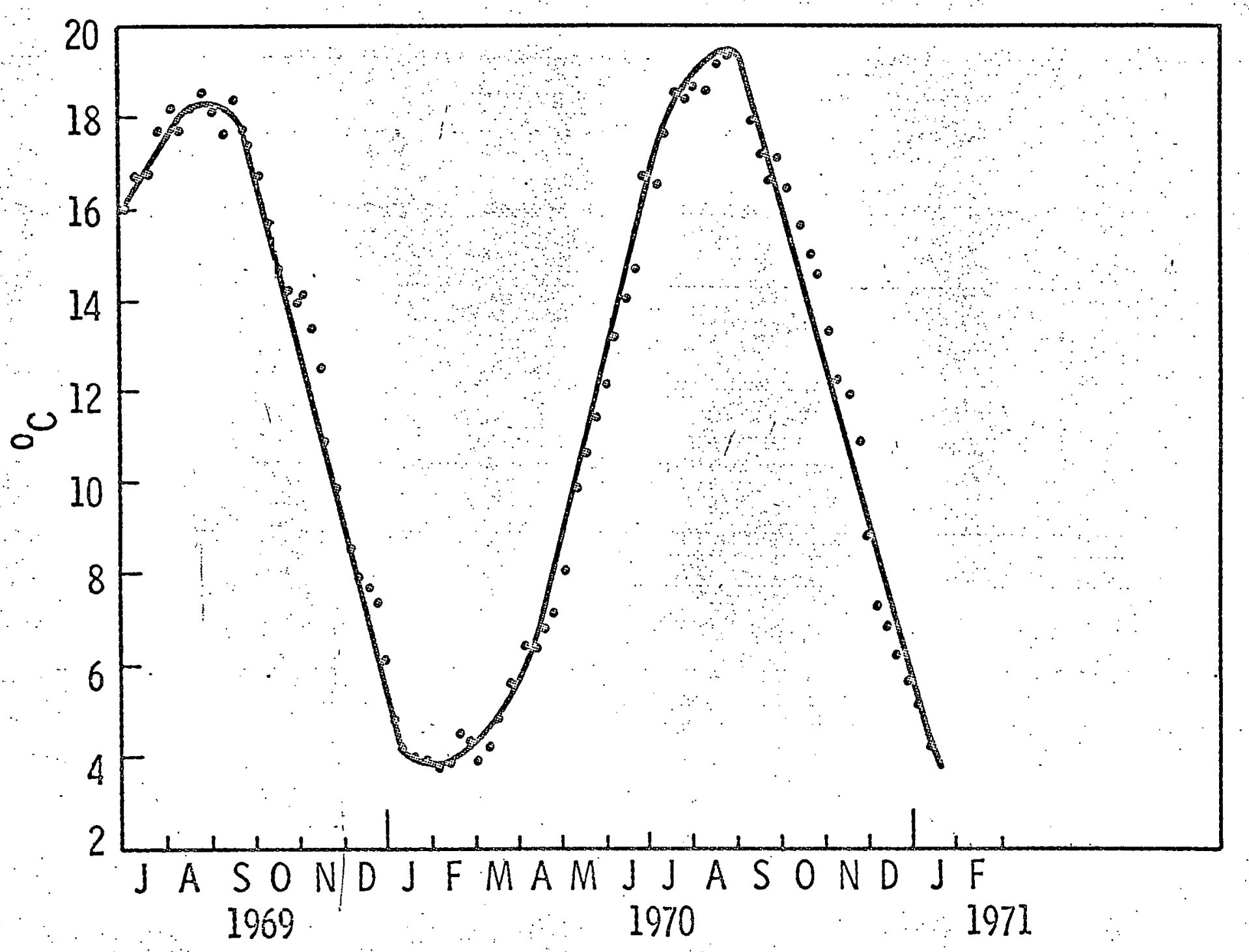




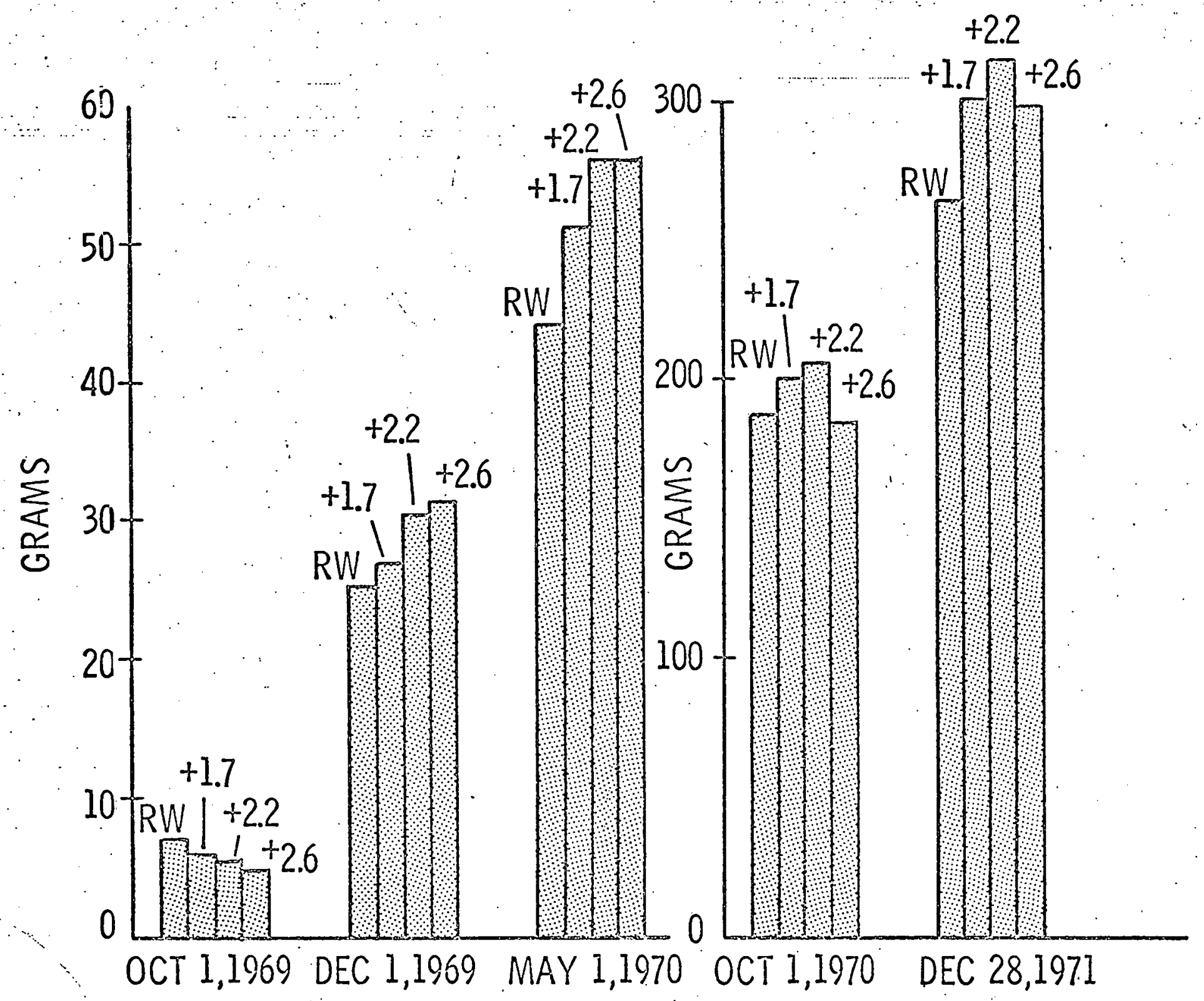




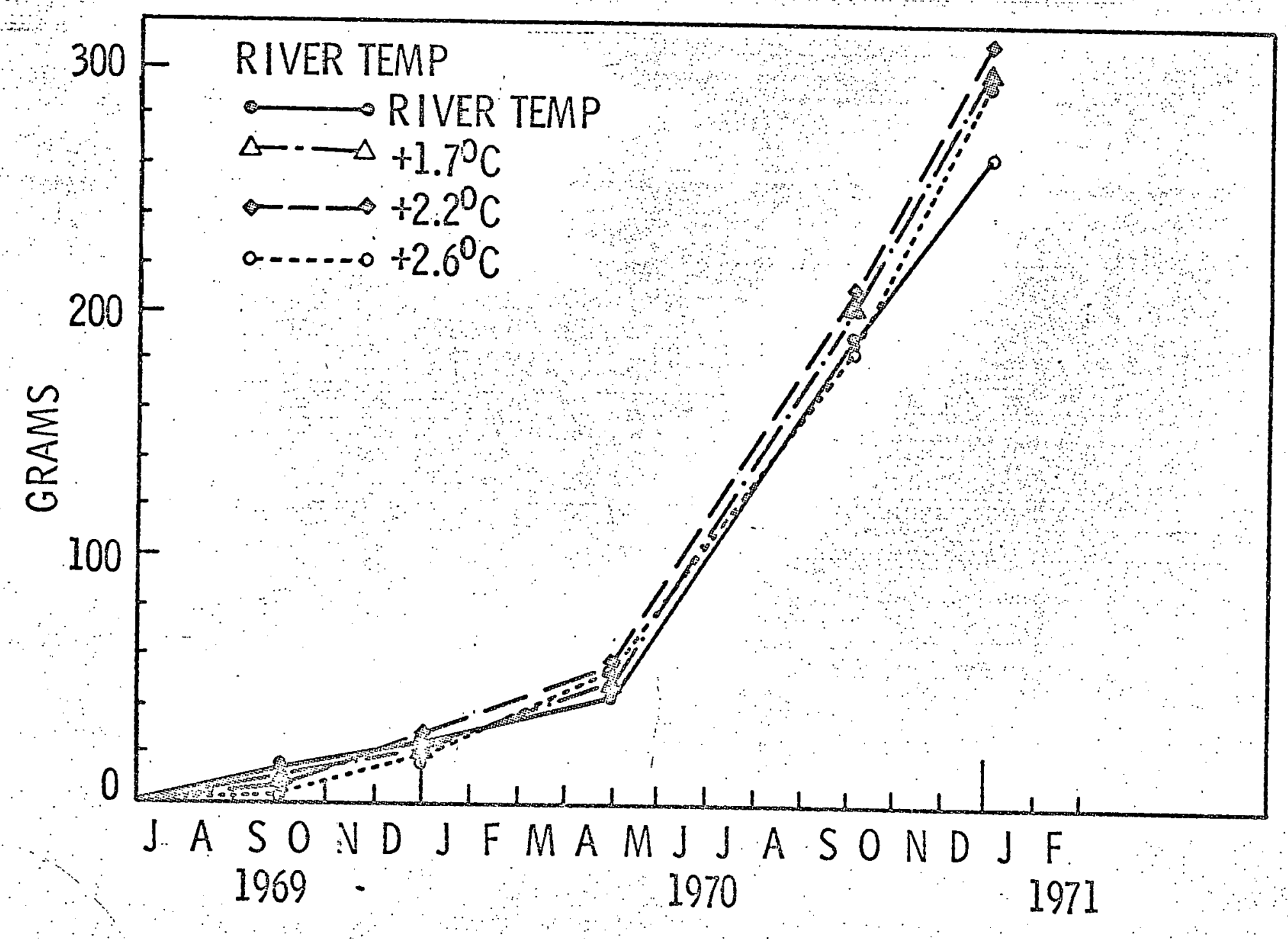



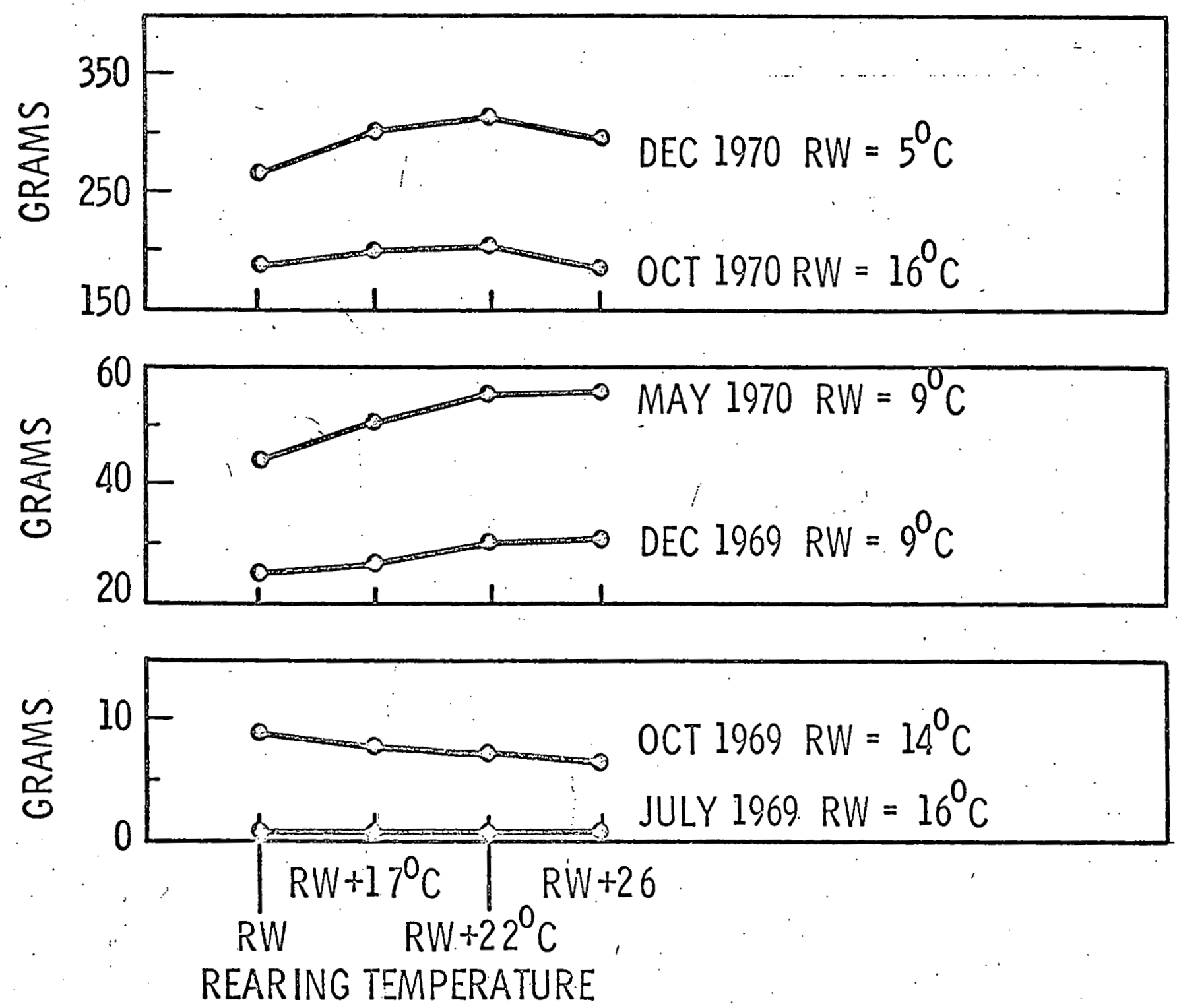